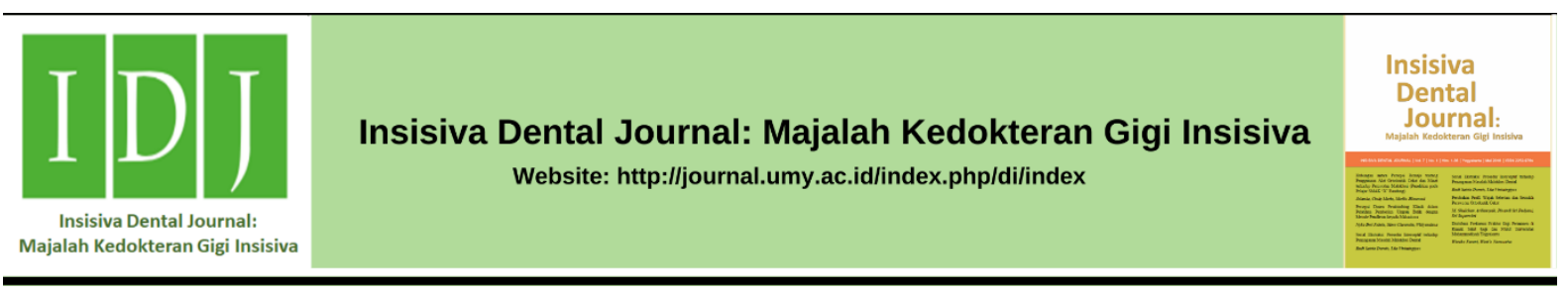

Research Article

\title{
Efektivitas Inkorporasi Platelet Rich Plasma pada Perancah Hidrogel $\mathrm{CaCO}_{3}$
}

\author{
The Effectiveness of Platelet Rich Plasma Incorporation into $\mathrm{CaCO}_{3} \mathrm{Hydrogel} \mathrm{Scaffold}$ \\ Erlina Sih Mahanani ${ }^{1 *}$, Khusnatunnisa ${ }^{2}$, Mutiah Mutmainnah ${ }^{2}$ \\ ${ }^{1}$ Departemen Dental Biomedika, Program Studi Kedokteran Gigi, Fakultas Kedokteran dan Ilmu Kesehatan, Universitas Muhammadiyah \\ Yogyakarta, Jalan Brawijaya, Tamantirto, Kasihan, Bantul, Indonesia. \\ ${ }^{2}$ Rumah Sakit Gigi dan Mulut, Universitas Muhammadiyah Yogyakarta, Jalan HOS Cokroaminoto No.17A, Pakuncen, Wirobrajan, \\ Yogyakarta, Indonesia.
}

Received date: June $21^{\text {st }}, 2019$; reviewed date: July $10^{\text {th }}, 2019$; revised date: August $26^{\text {th }}, 2019$; accepted date: October $1^{\text {st }}, 2019$ DOI : $10.18196 /$ di.8206

\begin{abstract}
Abstrak
Keberhasilan rekayasa jaringan ditentukan oleh tiga komponen yaitu perancah sebagai lingkungan mikro, sel, dan molekul signal. Platelet rich plasma (PRP) merupakan salah satu sumber molekul signal karena mengandung banyak faktor pertumbuhan. Molekul signal harus berada bersama dengan perancah dan dapat dilepaskan secara bertahap seiring dengan proses degradasi perancah. Banyaknya PRP yang dapat diinkorporasikan ke dalam perancah merupakan faktor penting yang mempengaruhi keberhasilan rekayasa jaringan. Tujuan penelitian ini adalah mengetahui jumlah inkorporasi PRP dalam perancah hidrogel gelatin dan $\mathrm{CaCO}_{3}$ dalam berbagai konsentrasi. Metode penelitian ini adalah eksperimental laboratoris menggunakan lima macam perancah hidrogel $\mathrm{CaCO}_{3}$ dengan konsentrasi gelatin $\mathrm{CaCO}_{3}$ yang berbeda yaitu, 3:7, 6:4 dan perancah hidrogel tanpa $\mathrm{CaCO}_{3}(10: 0)$.

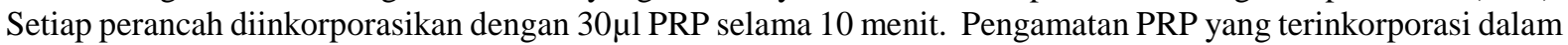
perancah menggunakan mikroskop cahaya yang dibagi dalam lima lapang pandang. Data yang diperoleh dianalis menggunakan ANOVA satu jalur dengan $\mathrm{p}<0,05$. Hasil menunjukkan bahwa rerata PRP yang terinkorporasi ke dalam perancah adalah 3:7 sebanyak 8.257,5; konsentrasi 6:4 sebanyak 4.792,2; dan konsentrasi 10:0 sebanyak 2.557. Kesimpulan penelitian ini adalah perancah dengan perbandingan gelatin dan $\mathrm{CaCO}_{3}$ 3:7 menghasilkan inkorporasi terbesar dibandingkan konsentrasi lainnya.
\end{abstract}

Kata Kunci: Hidrogel; Inkorporasi; Platelet rich plasma; Perancah

\begin{abstract}
The success of tissue engineering is determined by three components, namely the scaffold as a microenvironment, cells, and signaling molecules. Platelet rich plasma (PRP) is a source of signaling molecules as it contains a considerable amount of growth factors. Signal molecules must be there along with the scaffold and can be released gradually along with the degradation process of the scaffold. The number of platelets rich plasma that can be incorporated into scaffolding is an essential factor influencing the success of tissue engineering. This study aims to identify the number of incorporated PRP in gelatin hydrogel scaffold and CaCO3 in various concentrations. This study is an experimental laboratory study utilizing five kinds of CaCO3 hydrogel scaffold with different concentrations of $\mathrm{CaCO}$ gelatin, namely 3:7, 6:4, and hydrogel scaffold without CaCO3 (10:0). Each scaffold

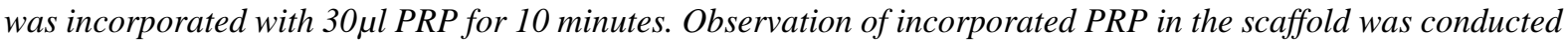
by using a light microscope in 5 visual fields. The data obtained were analyzed using one-way ANOVA with $p<0.05$. The results showed that the average incorporated PRP into scaffolding was 3:7 as much as 8,257.5, the concentration of 6:4 as much as 4,792.2, and a concentration of 10:0 as much as 2,557. It can be concluded that the scaffold with a ratio of gelatin and $\mathrm{CaCO} 33: 7$ produces the most significant incorporation compared to other concentrations.
\end{abstract}

Keywords: Hydrogel; Incorporation; Platelet rich plasma; Scaffold

* Corresponding author, e-mail: erlinasihmahanani@gmail.com 


\section{PENDAHULUAN}

Teknologi rekayasa jaringan menjadi pilihan ketika penyembuhan pada jaringan yang mengalami luka hanya memperbaiki jaringan non spesifik, sedangkan jaringan spesifik fungsional belum dapat diregenerasi. ${ }^{1}$ Teknologi rekayasa jaringan, merupakan teknologi yang sedang berkembang pesat, memiliki tiga komponen yang mempengaruhi keberhasilannya dalam meregenerasi jaringan, yaitu perancah (Scaffold), molekul signal dan sel. ${ }^{2}$ Perancah hidrogel adalah perancah yang berbahan dasar gelatin. Gelatin merupakan hasil dari hidrolisis parsial kolagen oleh produk alami dan merupakan protein yang mampu larut, terbuat dari kulit maupun tulang hewan. Gelatin tipe B merupakan gelatin yang berasal dari kulit dan tulang hewan yang sudah tua, proses hidrolisisnya dengan perendaman larutan basa dalam waktu yang cukup lama. Gelatin memiliki kandungan protein sangat tinggi sehingga memberikan fungsi sebagai pengikat, pemerkaya gizi, dapat membentuk lapisan tipis yang elastis, dapat membentuk film yang transparan, dan memiliki kekuatan yang baik. ${ }^{3}$

Kandungan lain selain gelatin sebagai bahan perancah adalah kalsium karbonat. Kalsium Karbonat $\left(\mathrm{CaCO}_{3}\right)$ merupakan bahan yang banyak terdapat di alam Indonesia, termasuk di Daerah Istimewa Yogyakarta. Bahan ini memiliki struktur yang mirip dengan matriks tulang manusia dan memiliki porusitas yang baik. Porusitas ini sangat penting karena memiliki peran untuk memfasilitasi sel dalam perlekatan, proliferasi, dan pembuangan metabolit. ${ }^{4}$

Molekul signal diperlukan dalam perancah untuk menstimuli sel berdiferensiasi menjadi sel target. Salah satu bahan yang sering digunakan adalah PRP karena mengandung banyak faktor pertumbuhan. Platelet rich plasma merupakan konsentrasi platelet dalam darah yang diperoleh dengan dua kali sentrifugasi. Platelet rich plasma mengandung banyak fatktor pertumbuhan yang sangat berperan dalam proses penyembuhan luka dan pembentukan jaringan lunak maupun keras. Kandungan yang ada di dalamnya antara lain, plateletderived growth factor (PDGF), transforming growth factor-B (TGF-b) 1 dan 2 serta vascular endothelial growth factor (VEGF). ${ }^{5,6}$

Regenerasi jaringan dalam teknologi rekayasa jaringan membutuhkan perancah sebagai tempat atau lingkungan mikro yang memfasilitasi sel untuk dapat melekat, tumbuh, berproliferasi dan berdiferensiasi sesuai dengan jaringan targer yang akan diregenerasi. Oleh karena itu diperlukan desain perancah yang baik dan sesuai.

Untuk meregenerasi suatu jaringan diperlukan molekul signal yang dapat diperoleh dari PRP yang banyak mengandung faktor pertumbuhan. Sedangkan sel dapat diperoleh dari lingkungan di sekitar area yang akan diregenerasi atau dapat pula ditambahkan dari luar ke dalam perancah. Molekul signal signal sebaiknya berada di dalam perancah, dan dapat terlepas secara periodik atau perlahan seiring dengan kebutuhan sel dan proses degradasi perancahnya, sehingga diharapkan saat perancah terdegradasi sempurna, sel sudah dapat mensekresikan jaringan baru. Oleh karena itu untuk fungsi ini diperlukan pemasukan molekul signal yang optimal ke dalam perancah.

Pemasukan atau inkorporasi molekul signal memberi peranan yang penting dalam keberhasilan rekayasa jaringan. Penelitian ini bertujuan untuk mengetahui efektifitas inkorporasi PRP pada perancah dengan konsentrasi yang berbeda-beda. $^{2,7}$

\section{MATERIAL DAN METODE}

Penelitian ini merupakan penelitian eksperimental laboratoris dan dilakukan di Laboratorium Patologi Anatomi dan Laboratorium Diagnostik Klinik Utama Asri Medical Center untuk pembuatan preparat dan preparasi PRP. Pengamatan 
mikroskopis dilakukan di Molecular Medicine Theraphy Laboratory UMY.

Perancah yang digunakan berbentuk membran tipis berbentuk lingkaran dengan diameter $16 \mathrm{~mm}$. Perancah difabrikasi di Laboratorium Terpadu Fakultas Kedokteran Gigi Universitas Gadjah Mada. Perancah berbahan dasar gelatin dan $\mathrm{CaCO}_{3}$ dengan konsentrasi yang berbeda - beda. Perbandingan antara gelatin dan $\mathrm{CaCO}_{3}$ adalah 3:7, 6:4 dan 10:0. Perancah berasal dari suspensi kedua bahan tersebut dan ditambah sodium sitrat sebagai dispersant ${ }^{8}$ dan dilakukan freeze drying serta physical cross-linking menggunakan metode dehidrotermal. ${ }^{9}$

Lima kelompok konsentrasi yang berbeda dilakukan inkorporasi PRP sebanyak $30 \mu \mathrm{l}$ per perancah dengan cara diteteskan ke atas perancah dan ditunggu selama 15 menit. Kemudian dilakukan fiksasi dan mounting pada deck glass untuk pengamatan mikroskopis. ${ }^{10}$

Pengamatan dilakukan pada 5 lapang pandang di setiap perancahnya, dan setiap lapang pandang dilakukan penghitungan banyaknya platelet yang melekat pada perancah sebanyak 3 kali. Data yang diperoleh dianalisis menggunakan ANOVA satu jalur.

\section{HASIL}

Hasil rerata jumlah PRP setelah diinkorporasikan pada perancah hidrogel $\mathrm{CaCO}_{3}$ ditunjukkan pada Tabel 1. Rerata tertinggi jumlah PRP yang terinkorporasi pada perancah adalah pada perancah dengan konsentrasi $3: 7$ sebanyak 8257,5.

Hasil uji statistik One Way ANOVA pada Tabel 2 menunjukkan nilai signifikansi $\mathrm{p}=0,007(\mathrm{p}<0,05)$, sehingga terdapat perbedaan yang signifikan antara perancah dengan berbagai konsentrasi.

Tabel 1. Rerata inkorporasi PRP

\begin{tabular}{cccc}
\hline Perancah & $\mathbf{3 : 7}$ & $\mathbf{6 : 4}$ & $\mathbf{1 0 : 0}$ \\
\hline PRP & 8257,5 & 4792,2 & 2557 \\
terinkorporasi & & & \\
\hline
\end{tabular}

Tabel 2. Hasil Uji ANOVA

\begin{tabular}{llllll}
\hline & $\begin{array}{l}\text { Sum of } \\
\text { Squares }\end{array}$ & df & $\begin{array}{l}\text { Mean } \\
\text { Square }\end{array}$ & F & Sig. \\
\hline $\begin{array}{l}\text { Between } \\
\text { Groups }\end{array}$ & 5499402,6 & 2 & 2749701,3 & 12.7 & $.007^{*}$ \\
$\begin{array}{l}\text { Within } \\
\text { Groups }\end{array}$ & 1295508,2 & 6 & 215918,0 & \\
Total & 6794910,8 & 8 & & & \\
\hline
\end{tabular}

Gambaran mikroskopis platelet rich plasma yang terinkorporasi pada perancah dipresentasikan pada Gambar 1.

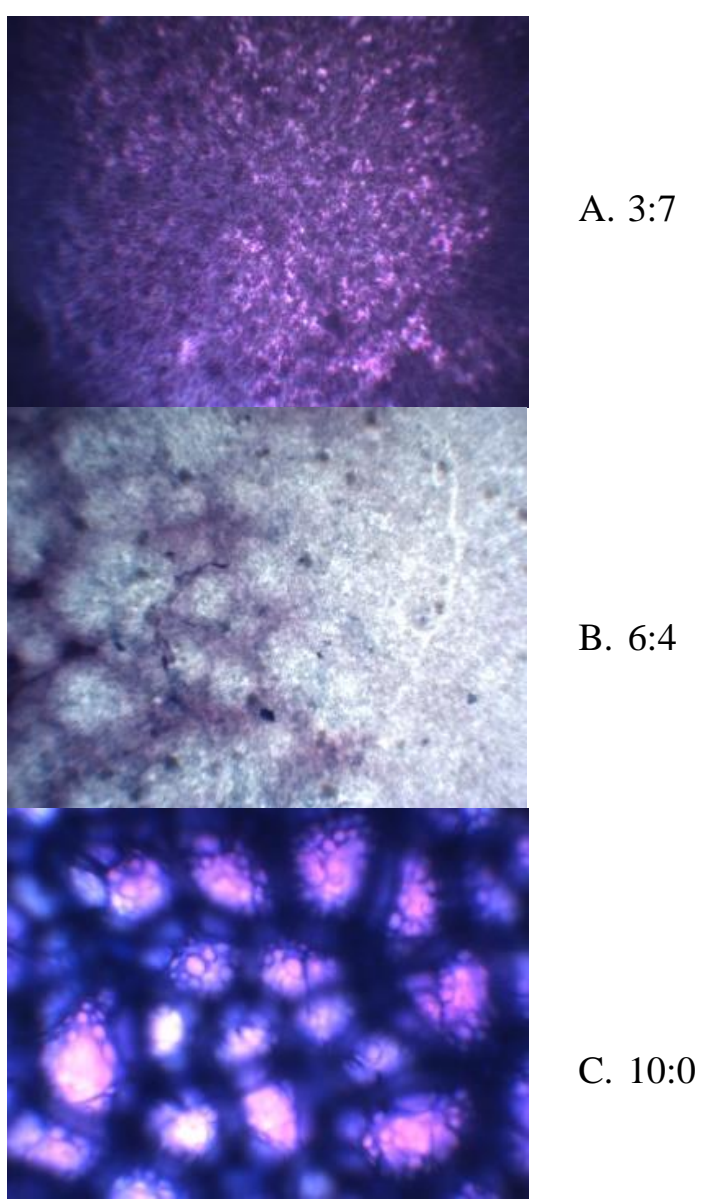

Gambar 1. Hasil pengamatan inkorporasi PRP pada perancah dengan berbagai konsentrasi menggunakan mikroskop cahaya dengan perbesaran 10x.

\section{PEMBAHASAN}

Perancah dengan perbandingan 3:7 adalah perancah yang memiliki kandungan gelatin paling rendah dan kandungan $\mathrm{CaCO}_{3}$ paling banyak dibandingkan konsentrasi $6: 4$ dan $10: 0$ yang merupakan perancah hidrogel tanpa penambahan $\mathrm{CaCO}_{3}$ sebagai kontrol. Jumlah yang 
didapatkan tersebut dipengaruhi oleh beberapa faktor diantaranya porusitas, swelling ability dan interface adherence pada perancah hirogel. ${ }^{11}$

Perbedaan konsentrasi perancah hidrogel ini memberikan pengaruh yang berbeda dalam perlekatan PRP yaitu pada struktur porusitas hidrogel, semakin kecil konsentrasi gelatin maka akan meningkatkan sifat porusitas dari perancah hidrogel tersebut. Porusitas yang besar akan memungkinkan lebih banyaknya PRP yang dapat melekat dalam perancah. Proses freeze-drying dari pembuatan perancah menciptakan gelatin menjadi stuktur berpori dan mampu menstabilkan jaringan. ${ }^{12}$

Kalsium karbonat $\left(\mathrm{CaCO}_{3}\right)$ yang menjadi salah satu bahan dasar perancah memiliki kemampuan biodegradasi secara natural lebih baik. Hal ini penting untuk keberhasilan rekayasa jaringan, karena diperlukan perancah yang dapat terdegradasi dengan sempurna setelah jaringan baru terbentuk. ${ }^{13}$

Kemampuan perancah dalam menyerap PRP dipengaruhi oleh 11 komponen yang menyertai yaitu biocompatibility, biodegradability, mechanical properties, structure, porosity, interface adherence, processabillity, nature, binding affinity, loading capacity release kinetics, dan stability. ${ }^{11}$

Seperti yang telah disebutkan bahwa perancah memiliki sifat-sifat yang saling berperan dalam penyerapan sel. Interface adherence yaitu suatu cara dari sebuah sel atau protein menempel pada permukaan perancah dan perancah yang digunakan harus dapat mendukung adhesi sel dan proliferasi sel tersebut serta memfasilitasi kontak sel-sel tersebut dan migrasinya. Porusitas atau struktur berpori dan ukuran pori yang dimiliki oleh perancah menentukan efisiensi masuknya sel-sel ke dalam perancah. ${ }^{4}$ Porusitas ini akan mempengaruhi pertumbuhan sel dan vaskularisasi sel dan meningkatkan transportasi metabolit. Perancah dengan pori yang terbuka serta tingkat porusitas yang tinggi sangat ideal bagi perancah untuk berinteraksi dan berintegrasi dengan jaringan host. Sehingga perancah dengan pori yang besar akan lebih efektif dalam menyerap sel. ${ }^{11}$

Selain interface adherence juga terdapat faktor penting yang dapat mempengaruhi penyerapan PRP kedalam perancah yaitu swelling ability yang merupakan salah satu kemampuan perancah dalam menyerap air yang berada disekitarnya. Kemampuan tersebut dipengaruhi oleh adanya gugus - gugus fungsi bebas yang terdapat didalam jaringan struktur molekulnya yang dapat mengikat air. Salah satu bahan yang terdapat didalam hidrogel adalah suprabsorben polimer yang mampu menyerap air dalam jumlah banyak dengan waktu yang singkat dan dapat menjaga air yang terserap didalamnya terikat. ${ }^{14}$.

Gelatin sangat memengaruhi struktur porusitas hidrogel. Pengaruh tersebut dikarenakan kandungan gelatin yang semakin tinggi akan mengakibatkan ukuran pori yang menjadi semakin kecil karena tingginya konsentrasi gelatin tersebut dapat meningkatkan ketebalan dinding pori. Ketebalan dinding pori dari perancah hidrogel meningkat jelas dengan gelatin yang lebih tinggi dibanding $\mathrm{CaCO}_{3}$. Sedangkan dengan konsentrasi yang lebih rendah menunjukan dinding pori yang lebih tipis dan berbentuk seperti jaring laba-laba. Hal itu terjadi karena kristal yang tumbuh melawan stuktur hidrogel yang berpengaruh pada kepadatan gel dan membuat ukuran dan morfologi kristal gel tersebut akan terlihat lebih jelas, sebalikya kristal pada perancah hidrogel akan menjadi semakin kecil dan memiliki permukaan yang lebih kasar karena kandungan padat dalam perancah hidrogel meningkat. ${ }^{15}$

Perancah dengan permukaan yang kasar mendukung dalam proses perlekatan, proliferasi dan diferensiasi dari sel-sel pembentuk tulang. Permukaan perancah diharapkan membentuk topografi nanometer dengan karakteristik yang 
mendekati ukuran protein disertai permukaan yang kasar dan bersifat kimiawi sehingga memungkinkan adanya proses traskripsi oleh lapisan protein menjadi informasi yang dapat dipahami oleh sel disekitarnya sehingga ikatan antar jenis sel tertentu dapat langsung ditargetkan. ${ }^{16}$

\section{KESIMPULAN}

Kesimpulan penelitian ini adalah perancah dengan perbandingan gelatin dan $\mathrm{CaCO}_{3}$ 3:7 menghasilkan inkorporasi terbesar dibandingkan konsentrasi lainnya yaitu sebanyak 8257,5.

\section{DAFTAR PUSTAKA}

1. Wang, M. Composite scaffolds for bone tissue engineering. Am. J. Biochem. Biotechnol. 2006; 2(2): 8084.

2. O'brien, F. J. Biomaterials \& scaffolds for tissue engineering. Mater. Today. 2011; 14(3): 88-95.

3. Hastuti, D., \& Sumpe, I. S. Pengenalan dan proses pembuatan gelatin. Mediagro; 2007; 3(1): 39-48.

4. Blackwood, K. A., Bock, N., Dargaville, T. R., \& Ann Woodruff, M. Scaffolds for growth factor delivery as applied to bone tissue engineering. Int J. Polym. Sci. 2012; 2012, 1-25.

5. Sánchez-González, D. J., MéndezBolaina, E., \& Trejo-Bahena, N. I. Platelet-rich plasma peptides: key for regeneration. Int . J. Pept. 2012; 2012. $1-10$.

6. Sadeghi-Ataabadi, M., MostafaviPour, Z., Vojdani, Z., Sani, M., Latifi, M., \& Talaei-Khozani, T. Fabrication and characterization of platelet-rich plasma scaffolds for tissue engineering applications. Mater. Sci. Eng. C. 2017; 71, 372-380.

7. Chen, G., Ushida, T., \& Tateishi, T. Scaffold design for tissue engineering. Macromol. Biosci. 2002; 2(2): 67-77.
8. Leeuwenburgh, S. C. G., Ana, I. D., \& Jansen, J. A. Sodium citrate as an effective dispersant for the synthesis of inorganic-organic composites with a nanodispersed mineral phase. Acta Biomater. 2010; 6(3), 836-844.

9. Mahanani, E. S., Bachtiar, I., \& Ana, I. D. Human mesenchymal stem cells behavior on synthetic coral scaffold. Key. Eng. Mater. 2016; 696, 205-211.

10. Mahanani, E. S., Farda, N., Tejaningasih, I., \& Khairunissa, N. The Effects of Platelet Rich Plasma Incorporation Towards Swelling Profile and Gel Fraction of Synthetic Coral Scaffold. In 2018 1st International Conference on Bioinformatics, Biotechnology, and Biomedical EngineeringBioinformatics and Biomedical Engineering. 2018; 1, 1-4.

11. Garg, T., Singh, O., Arora, S., \& Murthy, R. S. R. Scaffold: a novel carrier for cell and drug delivery. Crit. Rev. Ther. Drug. 2012; 29(1). 1-63.

12. Wattanutchariya, W., \& Changkowchai, W. Characterization of porous scaffold from chitosangelatin/hydroxyapatite for bone grafting. In Proceedings of the international multiconference of engineers and computer scientists. 2014; 2, 12-14.

13. El Fadhlallah, P. M., Yuliati, A., Soesilawati, P., \& Pitaloka, P. Biodegradation and Compressive Strength Test of Scaffold with Different Ratio as Bone Tissue Engineering Biomaterial. J. Int. Dent. Medical Res. 2018; 11(2), 587-590..

14. Abidin, A. Z., Susanto, G., Sastra, N. M. T., \& Puspasari, T. Sintesis dan karakterisasi Polimer Superabsorban dari Akrilamida. Jurnal Teknik Kimia Indonesia. 2012; 11(2), 87-93.

15. Nindiyasari, F., Fernandez-Diaz, L., Griesshaber, E., Astilleros, J. M., 
Sanchez-Pastor, N., \& Schmahl, W. W. Influence of gelatin hydrogel porosity on the crystallization of CaCO3. Cryst. Growth Des. 2014; 14(4), 1531-1542.

16. Henkel, J., Woodruff, M. A., Epari, D.
R., Steck, R., Glatt, V., Dickinson, I. C., ... \& Hutmacher, D. W. Bone regeneration based on tissue engineering conceptions-a 21st century perspective. Bone Res. 2013; 1 , 216-248. 